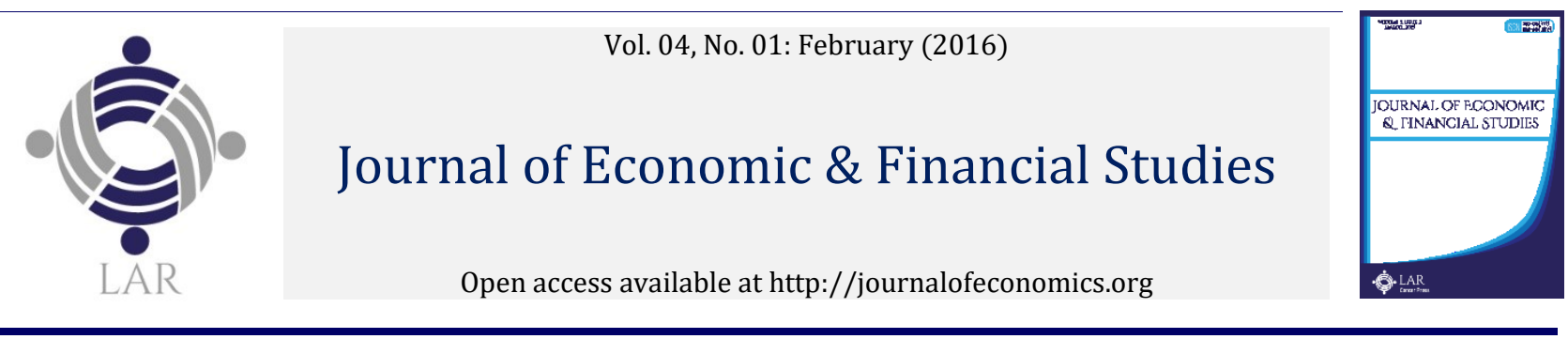

\title{
A comparison of Graham and Piotroski investment models using accounting information and efficacy measurement
}

\author{
Nusrat Jahana, John J. Cheh ${ }^{b}$, Il-woon Kim ${ }^{*}$ \\ a Assistant Professor, Department of Accounting \& Information Systems, Faculty of Business Studies, University of Dhaka. \\ b Professor, George W. Daverio School of Accountancy, College of Business Administration, The University of Akron. \\ c Professor, George W. Daverio School of Accountancy, College of Business Administration, The University of Akron. OH 44325. \\ *Corresponding author's email address: ikim1@uakron.edu
}

\section{A R T I C L E IN F O}

Received: 18-02-2016

Accepted: 04-03-2016

Available online: 10-03-2016.

Keywords:

Investment models;

Ranking;

Rebalancing periods;

Screening.

JEL Classification:

M40; G1; G12; G17.

\begin{abstract}
A B S T R A C T
We examine the investment models of Benjamin Graham and Joseph Piotroski and compare the efficacy of these two models by running backtest, using screening rules and ranking systems built in Portfolio 123. Using different combinations of screening rules and ranking systems, we also examine the performance of Piotroski and Graham investment models. We find that the combination of Piotroski and Graham investment models performs better than S\&P 500. We also find that the Piotroski screening with Graham ranking generates the highest average annualized return among different combinations of screening rules and ranking systems analyzed in this paper. Overall, our results show a profound impact of accounting information on investor's decision making.
\end{abstract}

(C) 2016 The Authors. This is an open access article under the terms of the Creative Commons Attribution License 4.0, which allows use, distribution and reproduction in any medium, provided the original work is properly cited.

DOI: http://dx.doi.org/10.18533/jefs.v4i1.219

\subsection{Introduction}

There are numerous research papers (Kogan \& Papanikolaou, 2013; North \& Stevens, 2015) written on the topic of stock investing. Depending on the assumption that past investment, profitability, valuation ratios, market betas, and idiosyncratic volatility are related to the ratio of growth opportunities to firm value, Kogan \& Papanikolaou (2013) proposed explanations for the empirical relations between firm characteristics and average returns. North \& Stevens (2015) analyzed performance of 56 portfolios of the American Association of Individual Investors (AAII) over the period of 1998 to 2011 and ranked all portfolios from best to worst, considering transaction costs and different measures of performance. Moreover, a number of competing investment models (Graham, Dodd, \& Cottle, 1934; Piotroski, 2000) have been proposed and empirically tested to demonstrate that these models could beat the market and produce abnormal returns. Among them, Portfolio 123 selects and showcases seven star investment models. ${ }^{1}$ These star models are based on strategies advocated by seven well-known stock investing experts: Joseph Piotroski, Martin Zweig, Joel Greenblatt, Benjamin Graham, William O'Neil, Peter Lynch, and Warren Buffett. The excellent performance of each model is well documented in this article as listed in different

\footnotetext{
${ }^{1}$ Portfolio123 provides the data on financial statements for retail investors to do basic financial analyses and also supplies a sophisticated high level computer language that allows professional investors to build custom formulas and experiment with various value investing strategies. In addition, each star model has been backtested with screening rules and ranking systems. Portfolio123 also has an extensive database and different investment strategies expressed in formulas. Investors can make analysis of their investment strategies applying different screening or ranking methods. See portfolio123.com for more details.
} 
tables. Using the rules and rankings available in Portfolio123, James, et al. (2014) lately examined the star models in Portfolio123 and found that Piotroski investment model generates the highest average return, Zweig's model shows the most volatility, and Buffett's model produces the highest beta score. Among the star models, the Piotroski model is perhaps the most comprehensive and relies heavily on accounting information (James, et al. 2014).

In this paper, we examine the investment models of Benjamin Graham and Joseph Piotroski and compare the efficacy of these two models, using different combinations of screening rules and ranking systems. We primarily focus on examining the screening rules of Graham and Piotroski star models, while pairing with different sets of ranking systems suggested by the star investment experts or implied in the star investment experts' strategies. The main goal of the examination is to obtain long-term stable returns in good periods and survive in bad economic conditions.

There are some rationales for choosing only Graham and Piotroski screening rules out of the seven star models. This research is aimed at focusing on investors, who prefer to get long term benefit as well as to survive in bad situations. Graham and Piotroski screenings are focused mainly on conservative investors. Conservative strategy performs better than exciting adventures into the risky fields of anticipated growth (Graham and Zweig, 2003). Interestingly, despite the fact that modern investors are so much more demanding, Graham investment strategies seem fairly effective even today. According to the explanations in Portfolio123, Graham investment model focuses on the conservative investor, who wants companies that appear better able to survive the worst business and economic storms. Graham, Dodd, \& Cottle (1934) differentiated between investment and speculation. Investment is a thorough analysis maintaining safety of principal and ensuring an adequate return, whereas speculation does not follow any thorough analysis (Graham et al., 1934). Moreover, Piotroski investment strategy illustrated in Porfolio123 is for conservative investors, who stress value and company quality. Investment model can create a stronger value portfolio by using simple screens based on historical financial performance (Piotroski, 2000). Other star models including investment models proposed by Zweig, O'Neil, and Lynch focus on aggressive investors. Greenblatt investment model focuses on less aggressive investors and uses modest variables, which are too simple to handle different complex situations. Buffet investment model is influenced by Graham investment model. So, among these different all-star screenings, we choose Graham and Piotroski screenings, concentrating on conservative investors and avoiding duplicity.

In addition, both of these investment models focus on solid accounting metrics, excluding non-accounting facts and show effectiveness in producing abnormal returns and beating market indices. Fundamental investors care for company's accounting information including company's balance sheet, and income statement, whereas technical investors avoid accounting metrics, focusing on price movements and volume of any security (Greenwald, Kahn, Sonkin, and Van Biema, 2004). Other star models work well for the investors, but these models use non-accounting information, which is considered speculative, more heavily (along with accounting information). Belmonte (2015) finds that a better strategy of investing is to find out the efficient companies, which are competent in using their asset base to earn profits for shareholders, based on accounting information.

This study will provide useful investment information for retail investors to manage their own retirement assets on a conservative and long-term basis, considering the fact that investors tend to use momentum investing strategies mainly due to the lack of knowledge in accounting and the cost of acquiring data needed for executing value investing strategies. Moreover, comparative analysis of stock investment models examined in this paper will also provide additional information to investors, who may need to decide which investment philosophy will work best for them.

This paper is organized as follows. First, we provide research design explaining screening rules, ranking systems, holding periods, and testing periods. Next, we provide empirical results followed by discussions. We use different measures including average annualized return, variability of return, correlation with S\&P 500, and beta score to analyze the performance of different combinations of screening rules and ranking systems. After discussing results, the last section of this study will provide concluding remarks.

\subsection{Research design}

In Portfolio123, investment strategies of the seven star models are translated into algorithm and designed with screening and ranking processes. Using these models, fourteen combinations of screening rules and ranking systems are backtested in this paper to get fifteen best stocks. First, among different screening rules of the star models built in Portfolio123, we choose screening rules of Graham and Piotroski investment models in this research. In the screening process, stocks are chosen or dropped based on the screening criteria used by Graham and Piotroski. In this process, we exclude American Depository Receipt (ADR). Then, we pair Graham and Piotroski screening methods with seven different ranking systems for testing. It should be noted that the ranking 
system is not used to drop or choose any stocks, but used to rank them from best to worst. For comparison, we use S\&P 500 as a benchmark.

Testing period is from January 1999 to December 2014, because the Portfolio123 database provides return data from 1999 onward. For each combination, we compare return and risk data such as, average return, maximum return, minimum return, average standard deviation, average R-squared, and average beta. Since the results may vary for using different start dates and different ending dates, we calculate average risk and return, considering different start dates of the investment for testing. Start dates are January 1999, February 1999, March 1999, April 1999, May 1999, June 1999, July 1999, August 1999, September 1999, October 1999, November 1999, and December 1999. For different start dates, we use the same date, December 23, 2014. Rebalancing a portfolio periodically should also be tested, for, using broad U.S. stock and bond market data from 1926 through 2009, Vanguard Investment Strategy group found that there is no optimal frequency or threshold when selecting a rebalancing strategy. Their analysis demonstrates that the risk-adjusted returns are not meaningfully different if a portfolio is rebalanced monthly, quarterly, or annually. To minimize the risk associated with portfolio drift, investors can use several possible triggers to determine when to rebalance such as, time-only, threshold-only, and time-and-threshold strategies (Jaconetti, Kinniry, and Zilbering, 2010). In this study, we follow time-only strategy, which depends on a set time schedule such as, monthly, quarterly, annually, and so on. Specifically, we use different rebalancing periods of 1-year, 6-month, 3-month, and 4-week. Through selecting such rebalancing periods, we hope to find optimal rebalancing periods for investors.

In the first stage of this study, we examine Graham screening with seven different ranking systems using Portfolio123. Initially, we choose Graham screening paired with Buffet ranking to run the backtest for getting the fifteen best companies. In the same way, we run the backtest of other six combinations such as, Graham Screening rules and Greenblatt ranking system, Graham screening and Lynch ranking, Graham screening and O'Neil ranking, Graham screening and Piotroski ranking, Graham screening and Zweig ranking, and Graham screening and Graham ranking in Portfolio123.

In the second stage, we backtest Piotroski screening rules with seven different ranking systems. In this backtesting, we select seven different ranking systems paired with Piotroski screening rules. These ranking systems are based on investment strategies proposed by Buffett, Greenblatt, Lynch, O'Neil, Graham, Zweig, and Piotroski. We present some important factors of Graham and Piotroski screening rules and seven different ranking systems in Table 1.

\begin{tabular}{|c|c|}
\hline \multicolumn{2}{|r|}{ Table 1: Factors of Graham and Piotroski screening rules and seven different ranking systems ${ }^{2}$} \\
\hline Screening & Factors \\
\hline Graham & Excluding OTC stock, current ratio, long term debt, EPS, and common dividend \\
\hline Piotroski & $\begin{array}{l}\text { Latest quarter price to book value and fundamentals based on gross margin, cash from operations, } \\
\text { debt to asset, asset turnover, ROA, and shares outstanding }\end{array}$ \\
\hline Ranking & Factors \\
\hline Buffet & $\begin{array}{l}\text { Book value based on five year growth rate, valuation based on market capitalization, business income, } \\
\text { price to book value, price to cash flow, and earnings quality based on stability, cleanliness of income } \\
\text { statement }\end{array}$ \\
\hline Greenblatt & Return on capital and earnings yield \\
\hline Lynch & $\begin{array}{l}\text { Valuation based on P/E, PEG ratio, prominence based on institutional ownership, published EPS } \\
\text { estimate, balance sheet, and company stature relative to industry }\end{array}$ \\
\hline O’Neil & EPS growth, Sales growth, industry EPS growth, market, company quality, and earnings stability \\
\hline Piotroski & $\begin{array}{l}\text { Latest quarter price to book value and fundamentals based on gross margin, cash from operations, } \\
\text { debt to asset, asset turnover, return on asset, and shares outstanding. }\end{array}$ \\
\hline Zweig & Growth based on standard EPS growth and acceleration in EPS and market performance \\
\hline Graham & $\begin{array}{l}\text { Valuation depending on } \mathrm{P} / \mathrm{E} \text {, price to book value, operating } \mathrm{P} / \mathrm{E} \text {, and earnings based on EPS } \\
\text { growth and stability }\end{array}$ \\
\hline
\end{tabular}

\subsection{Empirical results}

The overall performance of fourteen different combinations is summarized in table 2 and table 3 . Table 2 represents seven different combinations of Graham screening and other rankings. Seven other combinations of Piotroski screening and different rankings are shown in table 3. As different investors may select to rebalance for different periods such as, weekly, quarterly, monthly, or annually, we perform detailed test using various rebalancing periods. Table 4 through table 17 present the detailed statistics of four different rebalancing periods with fourteen combinations. Discussions on these results follow.

2 These factors are summarized from the illustration provided in Portfolio 123 
Table 2 summarizes the average of annualized return, volatility, R-squared, and beta score from Graham screening rules with all-star ranking systems. Graham screening rules with Graham ranking system show the highest return (16.75\%) among different combinations. The second highest average return is observed in Graham screening and Greenblatt ranking (16.50\%). However, Graham screening rules with O'Neil ranking system yield the lowest return of 7.62\%. It shows the highest volatility in Graham screening with O'Neil ranking with standard deviation of $23.42 \%$ and the lowest volatility in Graham screening with Piotroski ranking of 20.54\%. From table 3, we observe that the performance of Piotroski screening rules measured by average annualized return is far better than that of the Graham method for all combinations. We also observe the highest return of $21.61 \%$ in Piotroski screening with Graham ranking. Volatilities of Piotroski screening are slightly lower than those of Graham screening for all combinations.

\begin{tabular}{|c|c|c|c|c|c|c|}
\hline \multicolumn{7}{|c|}{ Table 2: Graham Screening Rules with Different Ranking Systems ${ }^{3}$} \\
\hline $\begin{array}{l}\text { Graham Screening } \\
+\end{array}$ & $\begin{array}{r}\text { Average of Annualized } \\
\text { Return (\%) }\end{array}$ & $\begin{array}{r}\text { Maximum } \\
\text { Return (\%) }\end{array}$ & $\begin{array}{r}\text { Minimum } \\
\text { Return (\%) }\end{array}$ & $\begin{array}{l}\text { Average Std. } \\
\text { Deviation (\%) }\end{array}$ & $\begin{array}{r}\text { Average } \\
\mathrm{R} \text { - squared }\end{array}$ & $\begin{array}{r}\text { Average } \\
\text { Beta }\end{array}$ \\
\hline Buffet Ranking & $13.90 \%$ & $17.42 \%$ & $8.53 \%$ & $21.82 \%$ & 0.43 & 0.72 \\
\hline Greenbalt Ranking & $16.50 \%$ & $22.42 \%$ & $10.09 \%$ & $20.82 \%$ & 0.44 & 0.69 \\
\hline Lynch Ranking & $9.99 \%$ & $13.47 \%$ & $6.95 \%$ & $21.93 \%$ & 0.46 & 0.74 \\
\hline ONeil & & & & & & \\
\hline Ranking & $7.62 \%$ & $14.24 \%$ & $4.10 \%$ & $23.42 \%$ & 0.47 & 0.81 \\
\hline Piotroski Ranking & $14.11 \%$ & $17.09 \%$ & $9.23 \%$ & $20.54 \%$ & 0.42 & 0.67 \\
\hline Zweig Ranking & $9.00 \%$ & $13.25 \%$ & $3.21 \%$ & $21.75 \%$ & 0.46 & 0.73 \\
\hline Graham Ranking & $16.75 \%$ & $20.59 \%$ & $11.56 \%$ & $21.21 \%$ & 0.41 & 0.68 \\
\hline
\end{tabular}

Table 3: Piotroski Screening Rules with different ranking systems ${ }^{4}$

\begin{tabular}{|c|c|c|c|c|c|c|}
\hline $\begin{array}{l}\text { Piotroski Screening } \\
+\end{array}$ & $\begin{array}{r}\text { Average of } \\
\text { Annualized Return } \\
(\%)\end{array}$ & $\begin{array}{r}\text { Maximum } \\
\text { Return (\%) }\end{array}$ & $\begin{array}{r}\text { Minimum } \\
\text { Return (\%) }\end{array}$ & $\begin{array}{r}\text { Average Std. } \\
\text { Deviation (\%) }\end{array}$ & $\begin{array}{r}\text { Average R- } \\
\text { squared }\end{array}$ & $\begin{array}{r}\text { Average } \\
\text { Beta }\end{array}$ \\
\hline Buffet Ranking & $19.47 \%$ & $24.85 \%$ & $12.66 \%$ & $21.75 \%$ & 0.35 & 0.64 \\
\hline Greenbalt Ranking & $18.47 \%$ & $23.88 \%$ & $10.70 \%$ & $20.96 \%$ & 0.40 & 0.66 \\
\hline Lynch Ranking & $16.17 \%$ & $20.02 \%$ & $11.87 \%$ & $19.63 \%$ & 0.42 & 0.63 \\
\hline ONeil Ranking & $20.03 \%$ & $26.12 \%$ & $13.67 \%$ & $22.04 \%$ & 0.40 & 0.70 \\
\hline Graham Ranking & $21.61 \%$ & $27.64 \%$ & $10.05 \%$ & $22.69 \%$ & 0.33 & 0.66 \\
\hline Zweig Ranking & $18.28 \%$ & $23.86 \%$ & $12.80 \%$ & $20.78 \%$ & 0.39 & 0.65 \\
\hline Piotroski Ranking & $20.36 \%$ & $27.33 \%$ & $10.75 \%$ & $21.65 \%$ & 0.33 & 0.62 \\
\hline
\end{tabular}

Table 4 presents return and risk data from Graham screening with Buffet ranking for different holding periods. Average return is only $13.90 \%$ with average standard deviation of $21.82 \%$. The 4 -week rebalancing strategy generates the highest return of $16.86 \%$ with the highest standard deviation of $22.49 \%$ and the highest beta of 0.75 . Also, we find the lowest return with the lowest standard deviation, the lowest R-squared, and the lowest beta in 1-year holding period. The gap between maximum and minimum average return is $8.89 \%$. Table 5 presents detailed statistics of the performance of the Graham screening with Greenblatt ranking. We find the maximum return with the highest volatility in the 4-week rebalancing period and the minimum return with the lowest volatility in the 1 -year period. Also, the range of return is $12.33 \%$. The maximum return is $22.42 \%$ and the minimum return is $10.09 \%$. R-squared is more than $40 \%$, which is significant and presents average correlation with benchmark. Here, the 4-week holding period generates the highest average return among different holding periods.

\begin{tabular}{|c|c|c|c|c|c|c|}
\hline \multicolumn{7}{|c|}{ Table 4: Graham screening rules with Buffett ranking system in different holding periods ${ }^{5}$} \\
\hline Holding & Average & Maximum & Minimum & Average Std. & Average & Average \\
\hline Period & Return (\%) & Return (\%) & Return (\%) & Deviation (\%) & R-squared & Beta \\
\hline 1-Year & $11.50 \%$ & $13.96 \%$ & $8.53 \%$ & $21.24 \%$ & 0.43 & 0.69 \\
\hline 6-Month & $13.66 \%$ & $14.83 \%$ & $12.61 \%$ & $21.57 \%$ & 0.43 & 0.71 \\
\hline 3-Month & $13.58 \%$ & $15.82 \%$ & $12.09 \%$ & $21.98 \%$ & 0.44 & 0.73 \\
\hline 4-Week & $16.86 \%$ & $17.42 \%$ & $16.21 \%$ & $22.49 \%$ & 0.45 & 0.75 \\
\hline Avg., Max., and Min & $13.90 \%$ & $17.42 \%$ & $8.53 \%$ & $21.82 \%$ & 0.43 & 0.72 \\
\hline
\end{tabular}

\footnotetext{
3 Table 2 presents the results from backtesting of Graham screening rules and other ranking systems using Portfolio 123 . To get this average, maximum, and minimum result, we run the backtest using data from January 1999 to December 2014 and using different holding periods. 4 Table 3 presents the results from backtesting of Piotroski screening rules and other ranking systems using Portfolio 123 . To get this average, maximum, and minimum result, we run the backtest using data from January 1999 to December 2014 and using different holding periods.

${ }^{5}$ In table 4 and 5, average return, average standard deviation, average R-squared, and average betas are expressed in bold format, maximum return is presented in italic format, and minimum return is presented in underlined format.
} 
Table 5: Graham screening rules with Greenblatt ranking system in different holding periods

\begin{tabular}{lrrrrrr}
$\begin{array}{l}\text { Holding } \\
\text { Period }\end{array}$ & $\begin{array}{r}\text { Average } \\
\text { Return (\%) }\end{array}$ & $\begin{array}{r}\text { Maximum } \\
\text { Return (\%) }\end{array}$ & $\begin{array}{r}\text { Minimum } \\
\text { Return (\%) }\end{array}$ & $\begin{array}{r}\text { Average Std. } \\
\text { Deviation (\%) }\end{array}$ & $\begin{array}{r}\text { Average } \\
\text { R-squared }\end{array}$ & $\begin{array}{r}\text { Average } \\
\text { Beta }\end{array}$ \\
\hline 1-Year & $13.93 \%$ & $17.99 \%$ & $10.09 \%$ & $20.47 \%$ & 0.43 & 0.67 \\
6-Month & $14.97 \%$ & $17.07 \%$ & $12.06 \%$ & $20.62 \%$ & 0.43 & 0.68 \\
3-Month & $15.94 \%$ & $19.32 \%$ & $13.70 \%$ & $20.98 \%$ & 0.44 & 0.70 \\
4-Week & $21.17 \%$ & $22.42 \%$ & $20.40 \%$ & $21.22 \%$ & 0.46 & 0.72 \\
Avg., Max., and Min & $16.50 \%$ & $22.42 \%$ & $10.09 \%$ & $20.82 \%$ & 0.44 & 0.69
\end{tabular}

In table 6, we notice that the average return from Graham screening with Lynch ranking is only $9.99 \%$, with maximum $13.47 \%$ and minimum $6.95 \%$. The average return from the 6-month holding period is $10.95 \%$, which is the highest. The average return from the 1-year holding period is the lowest among returns from other holding periods. Also, we find the highest volatility in the 4-week rebalancing period and the lowest volatility in the 1-year rebalancing period. Table 7 shows the information related to Graham screening with O'Neil ranking. We find the highest average return in the 1-year holding period. The lowest average return with the lowest standard deviation in the 4-week holding period, and the highest standard deviation in the 6-month holding period are other observations. It is interesting to note that beta of this combination is 0.81 , which is the highest among all the combinations of investment. The range of return is $10.14 \%$. Maximum return is $14.24 \%$ and the minimum return is $4.10 \%$. Beta measures the extent of the movement of the price of the stocks of this combination related to benchmark. This combination represents the lowest return among different combinations.

\begin{tabular}{lrrrrrr}
\hline \multicolumn{7}{c}{ Table 6: Graham screening rules with Lynch ranking system in different holding periods } \\
\hline Holding & $\begin{array}{r}\text { Average } \\
\text { Return (\%) }\end{array}$ & $\begin{array}{r}\text { Maximum } \\
\text { Return (\%) }\end{array}$ & $\begin{array}{r}\text { Minimum } \\
\text { Return (\%) }\end{array}$ & $\begin{array}{r}\text { Average Std. } \\
\text { Deviation (\%) }\end{array}$ & $\begin{array}{r}\text { Average } \\
\text { R-squared }\end{array}$ & $\begin{array}{r}\text { Average } \\
\text { Beta }\end{array}$ \\
\hline 1-Year & $8.96 \%$ & $11.25 \%$ & $6.95 \%$ & $21.31 \%$ & 0.45 & 0.71 \\
6-Month & $10.95 \%$ & $13.47 \%$ & $8.87 \%$ & $21.79 \%$ & 0.46 & 0.74 \\
3-Month & $9.96 \%$ & $12.62 \%$ & $7.04 \%$ & $22.17 \%$ & 0.46 & 0.75 \\
4-Week & $10.08 \%$ & $12.05 \%$ & $8.55 \%$ & $22.47 \%$ & 0.47 & 0.77 \\
\hline Avg., Max., and Min & $9.99 \%$ & $13.47 \%$ & $6.95 \%$ & $21.93 \%$ & 0.46 & 0.74 \\
\hline
\end{tabular}

Table 7: Graham screening rules with O'Neil ranking system in different holding periods

\begin{tabular}{lrrrrrr} 
Holding & $\begin{array}{r}\text { Average } \\
\text { Period }\end{array}$ & $\begin{array}{r}\text { Maximum } \\
\text { Return (\%) }\end{array}$ & $\begin{array}{r}\text { Minimum } \\
\text { Return (\%) }\end{array}$ & $\begin{array}{r}\text { Average Std. } \\
\text { Deviation (\%) }\end{array}$ & $\begin{array}{r}\text { Average } \\
\text { R-squared }\end{array}$ & $\begin{array}{r}\text { Average } \\
\text { Beta }\end{array}$ \\
\hline 1-Year & $9.57 \%$ & $14.24 \%$ & $6.54 \%$ & $23.30 \%$ & 0.48 & 0.81 \\
6-Month & $7.72 \%$ & $12.65 \%$ & $4.10 \%$ & $23.63 \%$ & 0.47 & 0.81 \\
3-Month & $6.87 \%$ & $9.75 \%$ & $5.53 \%$ & $23.54 \%$ & 0.47 & 0.81 \\
4-Week & $6.32 \%$ & $7.56 \%$ & $4.30 \%$ & $23.19 \%$ & 0.47 & 0.80 \\
Avg., Max., and Min & $7.62 \%$ & $14.24 \%$ & $4.10 \%$ & $23.42 \%$ & 0.47 & 0.81 \\
\hline
\end{tabular}

Table 8 shows the results of backtesting of combination of Graham screening and Piotroski ranking. Graham screening with Piotroski ranking shows the maximum return with maximum volatility in the 4-week holding period and minimum return in the 6-month holding period. This combination presents $14.11 \%$ average return. We notice the highest average return in the 4-week rebalancing period. Also, we observe the lowest standard deviation in the 1-year holding period. The range of average return is $7.86 \% .42 \%$ of average R-squared interprets significant relationship between the movement of this combination and that of S \& P 500 index. In this paper, the Piotroski screening and Graham ranking generates the highest average return of $21.61 \% .{ }^{7}$ However, in the Graham screening with Piotroski ranking, we observe only $14.11 \%$ of average return.

\begin{tabular}{lrrrrrr}
\hline \multicolumn{7}{c}{ Table 8: Graham screening rules with Piotroski ranking system in different holding periods } \\
\hline Holding & $\begin{array}{r}\text { Average } \\
\text { Return (\%) }\end{array}$ & $\begin{array}{r}\text { Maximum } \\
\text { Return (\%) }\end{array}$ & $\begin{array}{r}\text { Minimum } \\
\text { Return (\%) }\end{array}$ & $\begin{array}{r}\text { Average Std. } \\
\text { Deviation (\%) }\end{array}$ & $\begin{array}{r}\text { Average } \\
\text { R-squared }\end{array}$ & $\begin{array}{r}\text { Average } \\
\text { Beta }\end{array}$ \\
\hline 1-Year & $12.74 \%$ & $15.12 \%$ & $10.02 \%$ & $20.00 \%$ & 0.41 & 0.64 \\
6-Month & $13.32 \%$ & $16.32 \%$ & $9.23 \%$ & $20.31 \%$ & 0.42 & 0.66 \\
3-Month & $14.45 \%$ & $16.44 \%$ & $11.46 \%$ & $20.64 \%$ & 0.42 & 0.67 \\
4-Week & $15.94 \%$ & $17.09 \%$ & $14.55 \%$ & $21.21 \%$ & 0.43 & 0.70 \\
\hline Avg., Max., and Min. & $14.11 \%$ & $17.09 \%$ & $9.23 \%$ & $20.54 \%$ & 0.42 & 0.67 \\
\hline
\end{tabular}

Table 9 presents detailed statistics including return, volatility, R-squared, and beta of the combination of Graham screening with Zweig ranking. This combination generates $9 \%$ of average return. We observe the maximum return

\footnotetext{
${ }^{6}$ In table 6 and 7, average return, average standard deviation, average R-squared, and average betas are expressed in bold format, maximum return is presented in italic format, and minimum return is presented in underlined format.

${ }^{7}$ For more details, see exhibit table 15

${ }^{8}$ In table 8 and 9, average return, average standard deviation, average R-squared, and average betas are expressed in bold format, maximum return is presented in italic format, and minimum return is presented in underlined format.
} 
in the 4-week holding period and the minimum return in the 1-year holding period. Also, the average return of this combination is the second lowest return among different combinations examined in this study. Maximum return in this combination is $13.25 \%$. However, minimum return is only $3.21 \%$. Average beta is significant as well as $\mathrm{R}$-squared, which is $46 \%$. The gap between maximum and minimum return is $10.04 \%$.

Table 9: Graham screening rules with Zweig ranking system in different holding periods

\begin{tabular}{lrrrrrr}
\multicolumn{7}{c}{ Table 9: Graham screening rules with Zweig ranking system in different holding periods } \\
Holding Period & $\begin{array}{r}\text { Average } \\
\text { Return (\%) }\end{array}$ & $\begin{array}{r}\text { Maximum } \\
\text { Return (\%) }\end{array}$ & $\begin{array}{r}\text { Minimum } \\
\text { Return (\%) }\end{array}$ & $\begin{array}{r}\text { Average Std. } \\
\text { Deviation (\%) }\end{array}$ & $\begin{array}{r}\text { Average } \\
\text { R-squared }\end{array}$ & $\begin{array}{r}\text { Average } \\
\text { Beta }\end{array}$ \\
\hline 1-Year & $8.98 \%$ & $13.25 \%$ & $3.21 \%$ & $21.83 \%$ & 0.46 & 0.74 \\
6-Month & $9.51 \%$ & $12.21 \%$ & $6.81 \%$ & $21.89 \%$ & 0.46 & 0.74 \\
3-Month & $8.52 \%$ & $12.27 \%$ & $5.58 \%$ & $21.44 \%$ & 0.45 & 0.72 \\
4-Week & $8.98 \%$ & $13.25 \%$ & $3.21 \%$ & $21.83 \%$ & 0.46 & 0.74 \\
\hline Avg., Max., and Min & $9.00 \%$ & $13.25 \%$ & $3.21 \%$ & $21.75 \%$ & 0.46 & 0.73 \\
\hline
\end{tabular}

Graham screening combined with Graham ranking generates the highest return (16.75\%) among the combinations using Graham screening rules and different ranking systems, as shown in table 10. In this combination, we notice the maximum return with the highest volatility and minimum return with the lowest volatility. The range of return is $9.03 \%$. Here, the 4 -week rebalancing period generates the highest average return. Maximum return is $20.59 \%$, whereas minimum return is $11.56 \%$.

\begin{tabular}{lrrrrrr}
\hline \multicolumn{7}{c}{ Table 10: Graham screening rules with Graham ranking system in different holding periods } \\
\hline $\begin{array}{l}\text { Holding } \\
\text { Period }\end{array}$ & $\begin{array}{r}\text { Average } \\
\text { Return (\%) }\end{array}$ & $\begin{array}{r}\text { Maximum } \\
\text { Return (\%) }\end{array}$ & $\begin{array}{r}\text { Minimum } \\
\text { Return (\%) }\end{array}$ & $\begin{array}{r}\text { Average Std. } \\
\text { Deviation (\%) }\end{array}$ & $\begin{array}{r}\text { Average } \\
\text { R-squared }\end{array}$ & $\begin{array}{r}\text { Average } \\
\text { Beta }\end{array}$ \\
\hline 1-Year & $13.63 \%$ & $15.51 \%$ & $11.56 \%$ & $20.26 \%$ & 0.39 & 0.63 \\
6-Month & $16.68 \%$ & $18.60 \%$ & $15.01 \%$ & $20.68 \%$ & 0.40 & 0.66 \\
3-Month & $17.16 \%$ & $20.59 \%$ & $14.31 \%$ & $21.42 \%$ & 0.42 & 0.69 \\
4-Week & $19.53 \%$ & $20.49 \%$ & $17.97 \%$ & $22.49 \%$ & 0.43 & 0.74 \\
\hline Avg., Max., and Min & $16.75 \%$ & $20.59 \%$ & $11.56 \%$ & $21.21 \%$ & 0.41 & 0.68 \\
\hline
\end{tabular}

Table 11 presents the performance of Piotroski screening rules and Buffett ranking system in different holding periods. We find the maximum return in the 4-week holding period with the highest average beta and the minimum return in the 1-year holding period. Also, the highest volatility is found in the 6-month holding period. The gap between the highest return and the lowest return is $12.19 \%$. Average R-squared is $35 \%$, which expresses that only $35 \%$ of the stock's movement of this combination can be explained by movement of S\&P 500 index.

Table 11: Piotroski screening rules with Buffett ranking system in different holding periods

\begin{tabular}{|c|c|c|c|c|c|c|}
\hline Holding & Average & Maximum & Minimum & Average Std. & Average & Average \\
\hline Period & Return (\%) & Return (\%) & Return (\%) & Deviation (\%) & R-squared & Beta \\
\hline 1-Year & $15.94 \%$ & $19.87 \%$ & $12.66 \%$ & $21.85 \%$ & 0.34 & 0.63 \\
\hline 6-Month & $19.47 \%$ & $22.46 \%$ & $16.31 \%$ & $22.21 \%$ & 0.33 & 0.63 \\
\hline 3-Month & $20.04 \%$ & $23.82 \%$ & $17.28 \%$ & $21.44 \%$ & 0.37 & 0.65 \\
\hline 4-Week & $22.45 \%$ & $24.85 \%$ & $20.73 \%$ & $21.49 \%$ & 0.38 & 0.66 \\
\hline Avg., Max., and Min & $19.47 \%$ & $24.85 \%$ & $12.66 \%$ & $21.75 \%$ & 0.35 & 0.64 \\
\hline
\end{tabular}

Table 12: Piotroski screening rules with Greenblatt ranking system in different holding periods ${ }^{10}$

\begin{tabular}{lrrrrrr}
\hline $\begin{array}{l}\text { Holding } \\
\text { Period }\end{array}$ & $\begin{array}{r}\text { Average } \\
\text { Return (\%) }\end{array}$ & $\begin{array}{r}\text { Maximum } \\
\text { Return (\%) }\end{array}$ & $\begin{array}{r}\text { Minimum } \\
\text { Return (\%) }\end{array}$ & $\begin{array}{r}\text { Average Std. } \\
\text { Deviation (\%) }\end{array}$ & $\begin{array}{r}\text { Average } \\
\text { R-squared }\end{array}$ & $\begin{array}{r}\text { Average } \\
\text { Beta }\end{array}$ \\
\hline 1-Year & $15.41 \%$ & $19.73 \%$ & $10.70 \%$ & $21.17 \%$ & 0.39 & 0.66 \\
6-Month & $17.51 \%$ & $22.13 \%$ & $13.83 \%$ & $21.29 \%$ & 0.38 & 0.66 \\
3-Month & $19.16 \%$ & $23.88 \%$ & $16.74 \%$ & $20.65 \%$ & 0.41 & 0.66 \\
4-Week & $21.80 \%$ & $23.20 \%$ & $20.86 \%$ & $20.73 \%$ & 0.43 & 0.68 \\
\hline Avg., Max., and Min & $18.47 \%$ & $23.88 \%$ & $10.70 \%$ & $20.96 \%$ & 0.40 & 0.66 \\
\hline
\end{tabular}

Table 12 shows the result from using combination of Piotroski screening and Greenblatt ranking. We find the maximum return in the 3-month holding period and minimum return in the 1-year holding period in Piotroski screening with Greenblatt ranking. The lowest volatility is found in the period of the maximum return and the highest standard deviation is found at the time of the 6-month holding period. We notice the highest beta in the 4-week rebalancing period. The gap between the highest return and the lowest return is $13.18 \%$, which is noticeable. Table 13 represents statistics including return, volatility, and movement of stock with the S\&P index

\footnotetext{
${ }^{9}$ In table 10 and 11, average return, average standard deviation, average R-squared, and average betas are expressed in bold format, maximum return is presented in italic format, and minimum return is presented in underlined format.

${ }^{10}$ In table 12 and 13, average return, average standard deviation, average R-squared, and average betas are expressed in bold format, maximum return is presented in italic format, and minimum return is presented in underlined format
} 
of the Piotroski screening with Lynch ranking. $16.17 \%$ is the average return from using the combination of Piotroski screening and Lynch ranking. Maximum return with maximum volatility and maximum beta is achieved in 4-week rebalancing period. We find the minimum return in the 1-year holding period. The range of return or gap between maximum and minimum return is $8.15 \%$. Average standard deviation is $19.63 \%$, which is the lowest volatility among fourteen different combinations used in this paper. Average R- squared between stocks of this combination and S\&P 500 is more than $40 \%$.

Table 13: Piotroski screening rules with Lynch ranking system in different holding periods

\begin{tabular}{lrrrrrr}
\multicolumn{7}{c}{ Table 13: Piotroski screening rules with Lynch ranking system in different holding periods } \\
$\begin{array}{l}\text { Holding } \\
\text { Period }\end{array}$ & $\begin{array}{r}\text { Average } \\
\text { Return (\%) }\end{array}$ & $\begin{array}{r}\text { Maximum } \\
\text { Return (\%) }\end{array}$ & $\begin{array}{r}\text { Minimum } \\
\text { Return (\%) }\end{array}$ & $\begin{array}{r}\text { Average Std. } \\
\text { Deviation (\%) }\end{array}$ & $\begin{array}{r}\text { Average } \\
\text { R-squared }\end{array}$ & $\begin{array}{r}\text { Average } \\
\text { Beta }\end{array}$ \\
1-Year & $14.27 \%$ & $16.75 \%$ & $11.87 \%$ & $19.85 \%$ & 0.41 & 0.64 \\
6-Month & $15.57 \%$ & $19.66 \%$ & $13.21 \%$ & $19.33 \%$ & 0.42 & 0.62 \\
3-Month & $15.83 \%$ & $18.80 \%$ & $13.97 \%$ & $19.44 \%$ & 0.42 & 0.63 \\
4-Week & $19.03 \%$ & $20.02 \%$ & $18.13 \%$ & $19.91 \%$ & 0.43 & 0.65 \\
Avg., Max., and Min & $16.17 \%$ & $20.02 \%$ & $11.87 \%$ & $19.63 \%$ & 0.42 & 0.63 \\
\hline
\end{tabular}

The results of the combination of Piotroski screening and O'Neil ranking is shown in table 14. This table highlights the maximum return, which is $26.12 \%$ in the 3-month holding period and the minimum return, which is $13.67 \%$ in the 1-year holding period. We notice the highest average return in the 4-week holding period. The range of return between maximum and minimum is $12.45 \%$. Also, the volatility is the highest in the 6-month rebalancing period and the lowest in the 4-week rebalancing period. Table 15 represents the results of the combination of Piotroski screening with Graham ranking. This combination generates the highest average return among all different combinations analyzed in this paper. It is noticeable that the maximum return is achieved with the lowest standard deviation in the 4-week holding period. We notice the minimum return in the 1-year holding period. Moreover, we find the maximum beta in the 4-week holding period and the maximum volatility in the 6-month rebalancing period. Also, the gap between maximum and minimum return is quite significant at $17.59 \%$.

\begin{tabular}{lrrrrrr}
\hline \multicolumn{7}{c}{ Table 14: Piotroski screening rules with O'Neil ranking system in different holding periods } \\
\hline $\begin{array}{l}\text { Holding } \\
\text { Period }\end{array}$ & $\begin{array}{r}\text { Average } \\
\text { Return (\%) }\end{array}$ & $\begin{array}{r}\text { Maximum } \\
\text { Return (\%) }\end{array}$ & $\begin{array}{r}\text { Minimum } \\
\text { Return (\%) }\end{array}$ & $\begin{array}{r}\text { Average Std. } \\
\text { Deviation (\%) }\end{array}$ & $\begin{array}{r}\text { Average } \\
\text { R-squared }\end{array}$ & $\begin{array}{r}\text { Average } \\
\text { Beta }\end{array}$ \\
\hline 1-Year & $16.75 \%$ & $20.95 \%$ & $13.67 \%$ & $22.26 \%$ & 0.39 & 0.70 \\
6-Month & $18.54 \%$ & $22.16 \%$ & $15.19 \%$ & $22.34 \%$ & 0.40 & 0.70 \\
3-Month & $22.01 \%$ & $26.12 \%$ & $19.32 \%$ & $21.93 \%$ & 0.41 & 0.70 \\
4-Week & $22.81 \%$ & $24.31 \%$ & $21.36 \%$ & $21.63 \%$ & 0.40 & 0.68 \\
\hline Avg., Max., and Min & $20.03 \%$ & $26.12 \%$ & $13.67 \%$ & $22.04 \%$ & 0.40 & 0.70 \\
\hline
\end{tabular}

\begin{tabular}{lrrrrrr}
\hline \multicolumn{7}{c}{ Table 15: Piotroski screening rules with Graham ranking system in different holding periods } \\
\hline $\begin{array}{l}\text { Holding } \\
\text { Period }\end{array}$ & $\begin{array}{r}\text { Average } \\
\text { Return (\%) }\end{array}$ & $\begin{array}{r}\text { Maximum } \\
\text { Return (\%) }\end{array}$ & $\begin{array}{r}\text { Minimum } \\
\text { Return (\%) }\end{array}$ & $\begin{array}{r}\text { Average Std. } \\
\text { Deviation (\%) }\end{array}$ & $\begin{array}{r}\text { Average } \\
\text { R-squared }\end{array}$ & $\begin{array}{r}\text { Average } \\
\text { Beta }\end{array}$ \\
\hline 1-Year & $16.31 \%$ & $21.38 \%$ & $10.05 \%$ & $23.00 \%$ & 0.32 & 0.66 \\
6-Month & $21.07 \%$ & $23.75 \%$ & $16.80 \%$ & $23.32 \%$ & 0.30 & 0.64 \\
3-Month & $23.07 \%$ & $27.06 \%$ & $20.00 \%$ & $22.34 \%$ & 0.35 & 0.66 \\
4-Week & $25.97 \%$ & $27.64 \%$ & $23.72 \%$ & $22.11 \%$ & 0.37 & 0.67 \\
\hline Avg., Max., and Min & $21.61 \%$ & $27.64 \%$ & $10.05 \%$ & $22.69 \%$ & 0.33 & 0.66 \\
\hline
\end{tabular}

Table 16 shows the performance of the combination of Piotroski screening with Zweig ranking. 18.28\% is the average return from this combination. This table highlights the highest average return in the 4-week rebalancing period. In this combination, the maximum return is achieved in the 4-week rebalancing period with the highest standard deviation. Also, the lowest return with the lowest standard deviation is observed in the 6-month holding period. The range of return is $11.06 \%$.

Table 17 represents screening and ranking methods of the same Piotroski model. This combination of Piotroski screening with Piotroski ranking yields the second highest average return among all different combinations. So, this is a noticeable performing combination generating good average return and beating the market. Maximum return with maximum standard deviation is observed in the 4-week rebalancing period. We find the minimum return with the lowest average beta in the 1-year holding period. The gap between maximum and minimum return is $16.58 \%$. Average volatility found in this combination is $21.65 \%$, which is significant. In this combination, average R-squared is less than $40 \%$. This value of R-squared represents less significant correlation between the return from this combination and that from S \& P 500 index.

\footnotetext{
11 In table 14 and 15, average return, average standard deviation, average R-squared, and average betas are expressed in bold format, maximum return is presented in italic format, and minimum return is presented in underlined format
} 


\begin{tabular}{lrrrrrr}
\hline \multicolumn{7}{c}{ Table 16: Piotroski screening rules with Zweig ranking system in different holding periods } \\
\hline $\begin{array}{l}\text { Holding } \\
\text { Period }\end{array}$ & $\begin{array}{r}\text { Average } \\
\text { Return (\%) }\end{array}$ & $\begin{array}{r}\text { Maximum } \\
\text { Return (\%) }\end{array}$ & $\begin{array}{r}\text { Minimum } \\
\text { Return (\%) }\end{array}$ & $\begin{array}{r}\text { Average Std. } \\
\text { Deviation (\%) }\end{array}$ & $\begin{array}{r}\text { Average } \\
\text { R-squared }\end{array}$ & $\begin{array}{r}\text { Average } \\
\text { Beta }\end{array}$ \\
\hline 1-Year & $15.84 \%$ & $18.79 \%$ & $13.57 \%$ & $20.71 \%$ & 0.39 & 0.64 \\
6-Month & $16.65 \%$ & $20.82 \%$ & $12.80 \%$ & $20.37 \%$ & 0.39 & 0.64 \\
3-Month & $18.40 \%$ & $21.30 \%$ & $15.52 \%$ & $20.41 \%$ & 0.39 & 0.63 \\
4-Week & $22.22 \%$ & $23.86 \%$ & $21.26 \%$ & $21.63 \%$ & 0.40 & 0.68 \\
\hline Avg., Max., and Min & $18.28 \%$ & $23.86 \%$ & $12.80 \%$ & $20.78 \%$ & 0.39 & 0.65 \\
\hline
\end{tabular}

\begin{tabular}{lrrrrrr}
\hline \multicolumn{7}{c}{ Table 17: Piotroski Screening Rules with Piotroski Ranking System in Different Holding Periods } \\
\hline $\begin{array}{l}\text { Holding } \\
\text { Period }\end{array}$ & $\begin{array}{r}\text { Average } \\
\text { Return (\%) }\end{array}$ & $\begin{array}{r}\text { Maximum } \\
\text { Return (\%) }\end{array}$ & $\begin{array}{r}\text { Minimum } \\
\text { Return (\%) }\end{array}$ & $\begin{array}{r}\text { Average Std. } \\
\text { Deviation (\%) }\end{array}$ & $\begin{array}{r}\text { Average R- } \\
\text { squared }\end{array}$ & $\begin{array}{r}\text { Average } \\
\text { Beta }\end{array}$ \\
\hline 1-Year & $16.43 \%$ & $22.62 \%$ & $10.75 \%$ & $21.62 \%$ & 0.31 & 0.60 \\
6-Month & $18.20 \%$ & $20.14 \%$ & $15.38 \%$ & $21.60 \%$ & 0.32 & 0.61 \\
3-Month & $21.61 \%$ & $23.79 \%$ & $19.66 \%$ & $21.63 \%$ & 0.34 & 0.63 \\
4-Week & $25.22 \%$ & $27.33 \%$ & $23.05 \%$ & $21.76 \%$ & 0.35 & 0.65 \\
\hline Avg., Max., and Min & $20.36 \%$ & $27.33 \%$ & $10.75 \%$ & $21.65 \%$ & 0.33 & 0.62 \\
\hline
\end{tabular}

To comprehend the performance of the best performing combination found in this paper compared to that of S\&P 500, graphical presentations of the average return from Piotroski screening with Graham ranking and that from S\&P 500 are shown in figures 1 to 4 . All of these four figures present the average return of Piotroski Screening and Graham ranking in different holding periods. The time period for this comparison is from 1999 to 2014 . Red line expresses the average return from using Piotroski Screening and Graham ranking. Blue line shows the average return of S\&P 500 Index. Figure 1 to 4 represent the performance of the 1-year holding period, 6-month holding period, the 3-month holding period, and the 4-week holding period respectively. Figures 1 to 4 show that in any holding period considered in this paper, the average return of the best performing combination is higher than that of S \& P 500 index.

Figure 1: Piotroski screening rules with Graham ranking system (1-year Rebalancing Period) - Start date $1 / 2 / 1999$ and end date $12 / 23 / 2014^{13}$

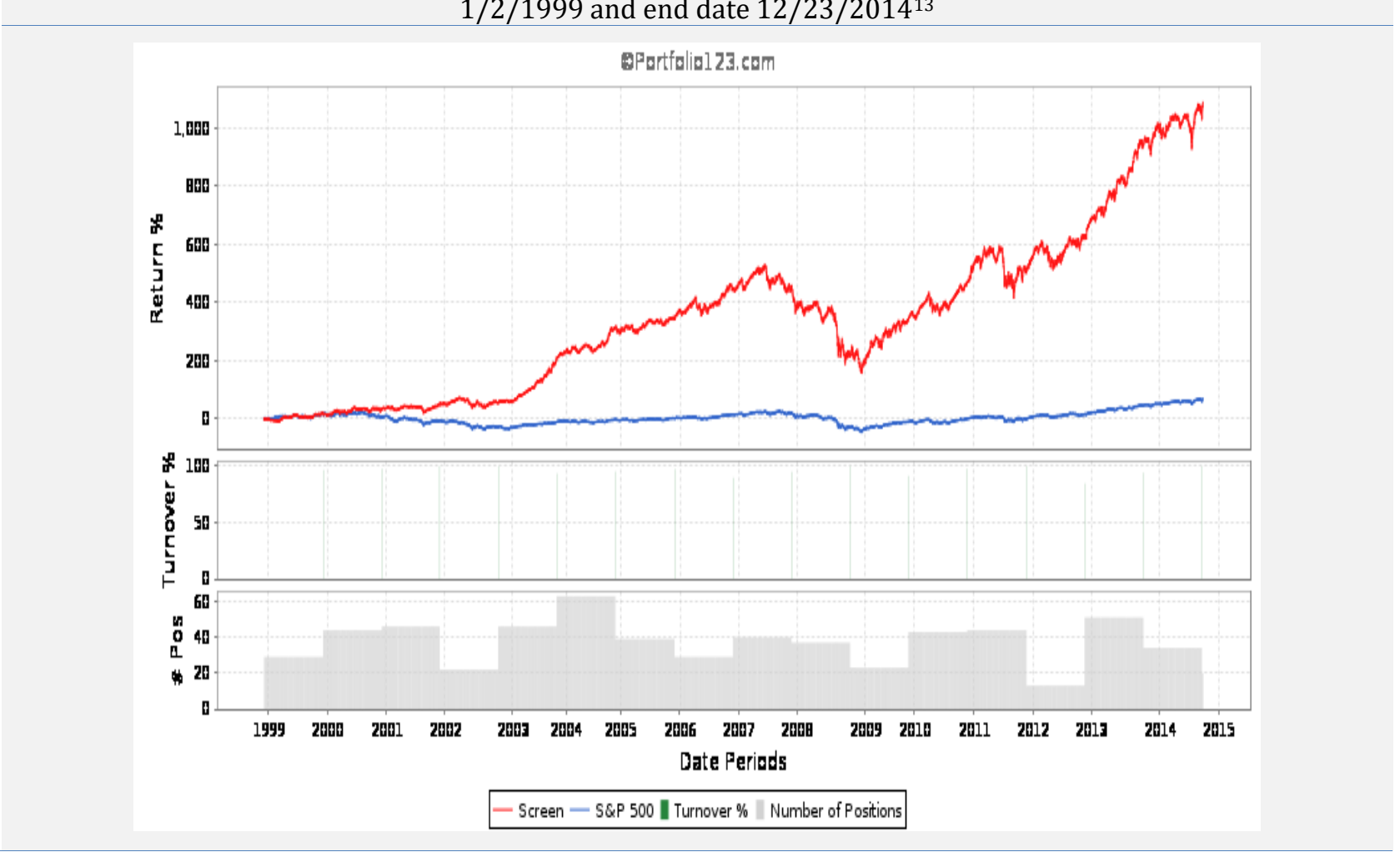

\footnotetext{
${ }^{12}$ In table 16 and 17, average return, average standard deviation, average R-squared, and average betas are expressed in bold format, maximum return is presented in italic format, and minimum return is presented in underlined format.

${ }^{13}$ This graph presented in figure 1, comparing the performance of Priotroski Screening and Graham ranking with that of S\&P 500, is generated in Portfolio 123 after running the backtest for 1-year
} 
Figure 2: Piotroski screening rules with Graham ranking system (6-month Rebalancing Period)-Start Date $1 / 2 / 1999$ and End Date $12 / 23 / 2014^{14}$

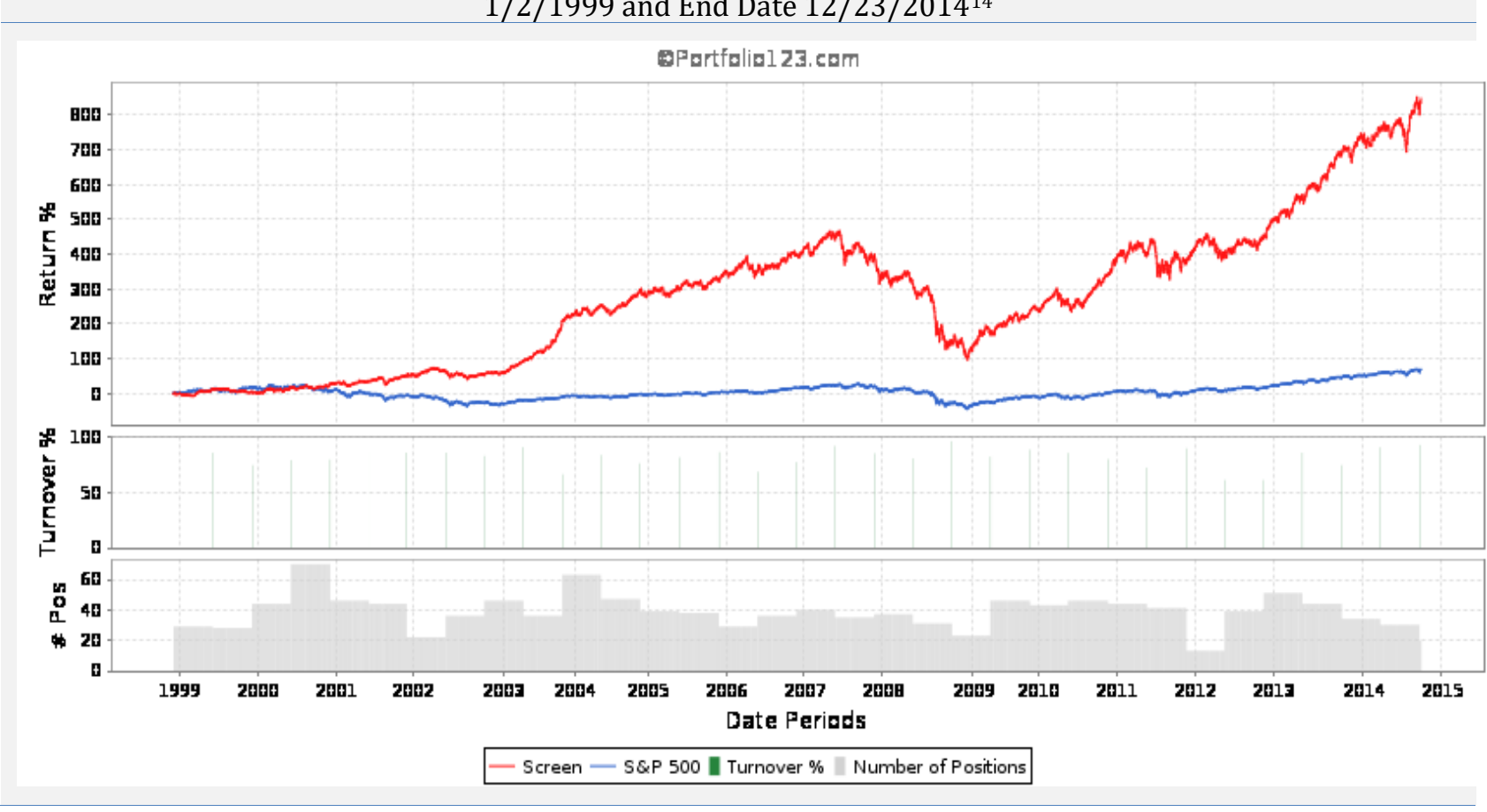

Figure 3: Piotroski screening rules with Graham ranking system (3-month Rebalancing Period)-Start Date $1 / 2 / 1999$ and End Date $12 / 23 / 2014^{15}$

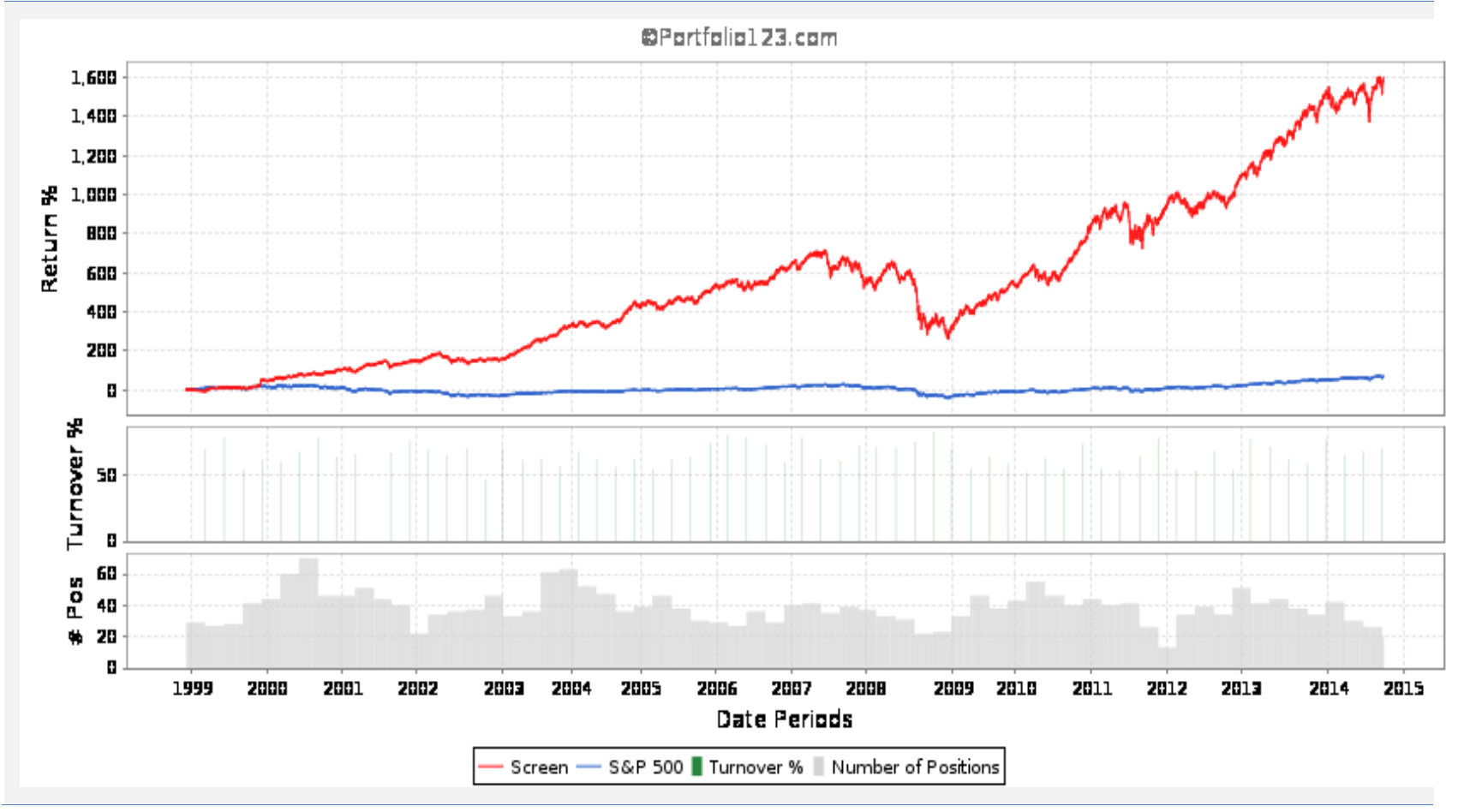

\footnotetext{
${ }^{14}$ This graph presented in figure 2, comparing the performance of Priotroski Screening and Graham ranking with that of S\&P 500, is generated in Portfolio 123 after running the backtest for 6-month

${ }_{15}$ This graph presented in figure 3, comparing the performance of Priotroski Screening and Graham ranking with that of S\&P 500, is generated in Portfolio 123 after running the backtest for 3-month
} 
Figure 4: Piotroski Screening Rules with Graham Ranking System (4-week Rebalancing Period)-Start Date $1 / 2 / 1999$ and End Date 12/23/201416

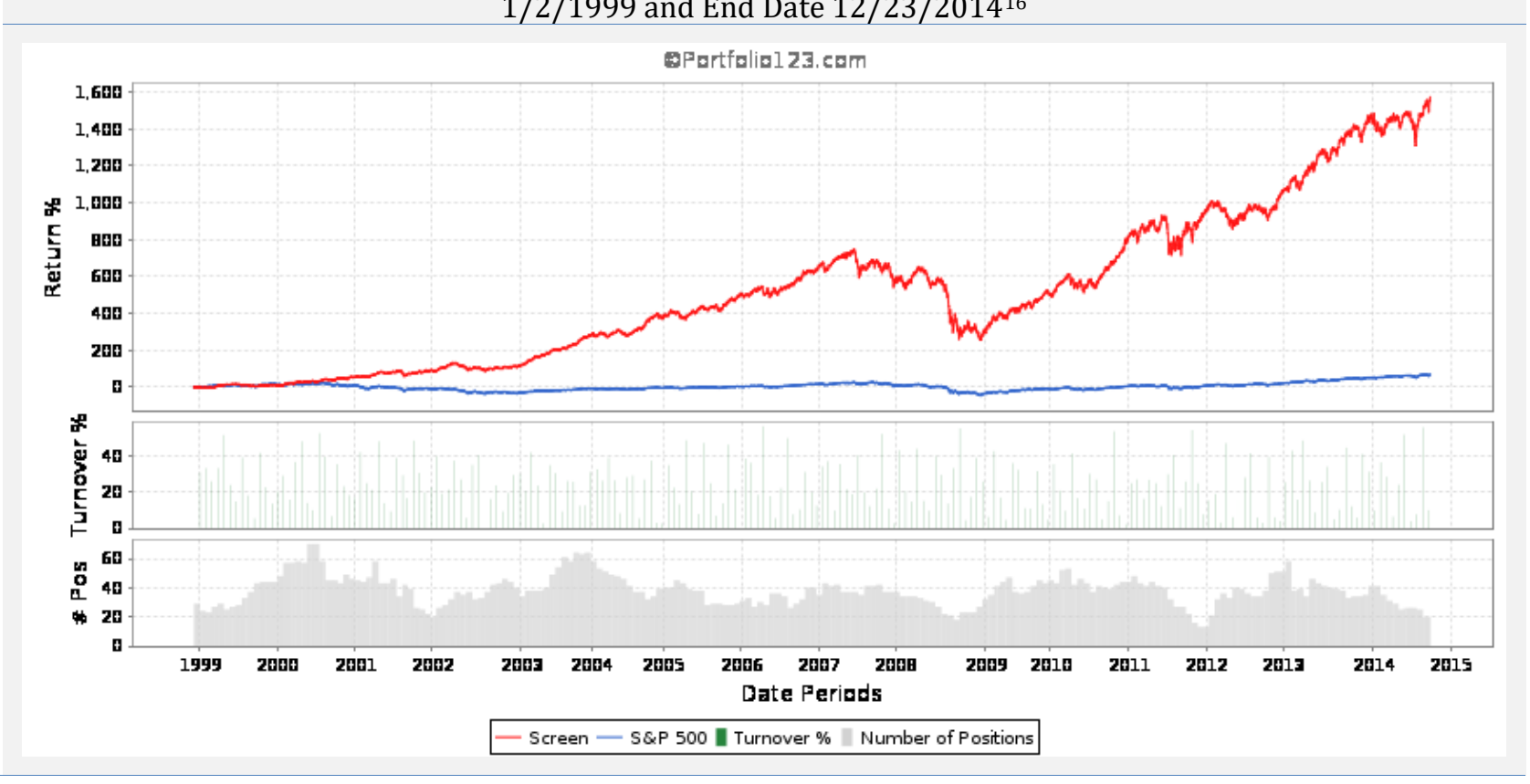

\subsection{Concluding remarks}

In our research, we analyze performance of two major investment strategies focusing on long term stable returns in good periods and survival in worst conditions. Hence, we backtest different combinations of screening rules and ranking systems. Depending on the results found in this backtesting of different combinations of screening rules of two investment models and ranking systems of all-star investment models, we notice that Piotroski screening with Graham ranking generates the highest average return with the second highest average volatility among different combinations. Moreover, considering performance of different combinations in different holding periods, we find that the combination of Piotroski screening with Graham ranking in the 4-week holding period generates the highest return. Moreover, we notice the highest volatility in the Graham screening with $0^{\prime}$ Neil ranking system. It is also surprising that the Piotroski screening with Graham ranking generates the highest return, whereas return from Graham screening with Piotroski ranking is insignificant. However, Piotroski screening with Piotroski ranking shows the second highest return.

The Piotroski screen has been one of AAII's top-performing screens for a number of years. While the S\&P 500 was down 1.0\% year-to-date as of February 28, 2010, AAII's Piotroski screen gained an unbelievable 96.4\% (Cara Scatizzi, 2010). In this paper, we find the two best performing combinations including Piotroski screening with Graham ranking and Piotroski screening with Piotroski ranking. In Piotroski screening with Graham ranking, average return is $21.61 \%$, maximum return is $27.64 \%$, minimum return is $10.05 \%$, and standard deviation is $22.69 \%$. On the other hand, Piotroski screening with Piotroski ranking shows average return of $20.36 \%$, maximum return $27.33 \%$, minimum return $10.75 \%$, and standard deviation $21.65 \%$. Between these two best performing combinations, the first combination generates higher return with higher standard deviation. Also, the gap between average return is similar. In both scenarios, the screening is the same, but the ranking system is different. Also, the ranking factors between Graham and Piotroski are different. Still, there are few deviations between the results of these two combinations. The results of this paper may vary for taking historical data of different start and end dates, considering different rebalancing periods, and facing anomalous situations.

This research could help investors in analyzing the performance of stocks depending on accounting information, which may represent the real scenario of performing stocks. Moreover, using different combinations presented in this paper, investors can screen and rank stocks depending on their investment amount. Considering the emerging fact that the defined contribution plans are becoming the new normal way of employee's preparing for retirement years (Benjamin VanMetre, 2014), investment simulation tools such as, Portfolio123 for backtesting provide rank-and-file employee-investors, who may not be able to afford expensive private investment managers, with an inexpensive way of managing their own retirement assets and determining the most optimal investment

16 This graph presented in figure 4, comparing the performance of Priotroski Screening and Graham ranking with that of S\&P 500, is generated in Portfolio 123 after running the backtest for 4-week 
strategy tailored for their investment objectives and long-term retirement future. Thus, this paper contributes significantly to the democratization of Wall Street by examining the efficacy of well-known investment strategies with a credible investment simulation tool.

\section{References}

Abel, A. B. (1983). Optimal investment under uncertainty. The American Economic Review, 73(1), 228-233.

Barro, R. J. (1990). The stock market and investment. Review of Financial Studies, 3(1), 115-131. http://dx.doi.org/10.1093/rfs/3.1.115

Belmonte, J. (2015). Buffett and beyond: Uncovering the secret ratio for superior stock selection. John Wiley \& Sons.

Benjamin VanMetre. (2014). 401(K)-style retirement plans are the new normal; illinois should get on board. Retrieved from https://www.illinoispolicy.org/401k-style-retirement-plans-are-the-new-normal-illinoisshould-get-on-board/

Cara Scatizzi. (2010). Adjusting for the real world: Testing variations of piotroski's screen. AAII Journal, April, 01 December 2014.

Graham, B., Dodd, D. L. F., \& Cottle, S. (1934). Security analysis. McGraw-Hill New York.

Graham, B., \& Zweig, J. (2003). The intelligent investor. Harper Business Essentials.

Greenwald, B. C., Kahn, J., Sonkin, P. D., \& Van Biema, M. (2004). Value investing: From graham to buffett and beyond. John Wiley \& Sons.

Jaconetti, C. M., Kinniry, F. M., \& Zilbering, Y. (2010). Best practices for portfolio rebalancing. Vanguard Research, July, 2010.

James, P., Cheh, J. J., \& Kim, I. (2014). A comparative analysis on performance of seven all star investment models. Pan-Pacific Journal of Business Research, 5(2), 23.

Kogan, L., \& Papanikolaou, D. (2013). Firm characteristics and stock returns: The role of investment-specific shocks. Review of Financial Studies, 26(11), 2718-2759. http://dx.doi.org/10.1093/rfs/hht026

Liu, H. (2014). Solvency constraint, underdiversification, and idiosyncratic risks. Journal of Financial \& Quantitative Analysis, 49(2), 409-430. http://dx.doi.org/10.1017/S0022109014000271

North, D. S., \& Stevens, J. L. (2015). Investment performance of AAII stock screens over diverse markets. Financial Services Review, 24(2), 157-176.

Piotroski, J. D. (2000). Value investing: The use of historical financial statement information to separate winners from losers. Journal of Accounting Research,1-41. nhttp://dx.doi.org/10.2307/2672906

\section{Appendix}

\section{Empirical Studies on Performance of Seven Star Models}

Warren Buffett

Holloway, P., Rochman, R., and Laes, M. (2013), "Factors influencing Brazilian value investing Portfolios", Journal of Economics, Finance and Administrative Science, Vol. 18, pp. 18- 22.

Martin, G. S., and Puthenpurackal, J. (2008), "Imitation is the sincerest form of flattery: Warren Buffett and Berkshire Hathaway, Working paper, American University.

Rajablu, M. (2011), "Value investing: review of Warren Buffett's investment philosophy and practice”, Research Journal of Finance and Accounting, Vol. 2 No. 4, pp.1-6.

Stulz, R. (2004), "Should we fear derivatives? Journal of Economic Perspectives, Vol. 18 No. 3, pp. 173-192.

Benjamin Graham

Athanassakos, G. (2012), "Value investing vs. modern portfolio theory" (editorial), Journal of Business and Financial Affairs, Vol. 1 No. 2, pp.1-2.

Basu, S. (1997), "Investment performance of common stocks in relation to their price to earning ratio: A test of the efficient market hypothesis", Journal of Finance, Vol. 32, pp. 663-682.

Greenwald, B. C. (2004), Value investing from Graham to Buffett and beyond. John Wiley and Sons Inc.

Kacperczyk, M., Sialm, C. and Zheng, L. (2005), “On the industry concentration of actively managed equity funds", Journal of Finance, Vol. 60, pp. 1983-2011.

Joel Greenblatt

Chan, L. K., and Lakonishok, J. (2004), "Value and growth investing: review and update", Financial Analysts Journal, Vol. 60 No. 1, pp. 71-86.

Greenblatt, J. (2006), The little book that beats the market. John Wiley and Sons, Hoboken. 
Larkin, P. J. (2009), “Can individual investors capture the value premium?” Journal of Business and Economics Research, Vol. 7 No. 5, pp. 25-34.

Sareewiwatthana, P. (2011), "Value investing in Thailand: the test of basic screening rules", International Research Papers,Vol 7 No.4, pp. 1-13.

\section{Peter Lynch}

Kosowski, R., Timmermann, A., Wermers, R., and White, H. (2006), "Can mutual fund stars really pick stocks? New evidence from a bootstrap analysis”, TheJournal of Finance, Vol.61 No. 6, pp. 2551-2596.

Porter, G. E., and Trifts, J. W. (2012), "The best mutual fund managers: testing the impact of experience using a survivorship-bias free dataset", Journal of Applied Finance, No.1, pp. 1-13.

Seasholes, M. S., and Zhu, N. (2013), "Investing in what you know: the case of individual investors and local stocks", Journal of Investment Management, Vol. 11 No. 1, pp. 20-30.

Ye, Y. (2013), "Application of the stock selection criteria of three value investors, Benjamin Graham, Peter Lynch, and Joel Greenblatt: a case of Shanghai stock Exchange from 2006- 2011", Internal Journal of Scientific and Research Publications, Vol. 3 No.8, pp. 2250-3153.

\section{William O'Neil}

Jordan, D., and Robertson, A. (2009), "Lack of momentum in the Investor Business Daily 100", Investment Management and Financial Innovations, Vol. 6, pp. 126-134.

O'Neil, W. (1988), How to make money in stock: A winning system in good times and bad. McGraw- Hill.

Senchack, A. J. (2012), "A test of composite measure for common stock momentum investing" Paper presented at the Academy of Financial Services conference. San Antonio, Texas.

Sharpe, W. (1992), "Asset allocation: management style and performance measurement. An asset class factor model can help make order out of chaos”, Journal of Portfolio Management (Winter), pp. 7-19.

\section{Joseph Piotroski}

Beukes, A. (2011), "Value investing: international comparison", Internal Business and Economics Research Journal Vol.10 No. 5, pp. 1-10.

Piotroski, J. (2000), "Value investing. The use of historical financial information to separate winners from losers", Journal of Accounting Research Vol. 38 No. 3, pp.1-41.

\section{Martin Zweig}

Anderson, S., Beard, T. R., Kim, H., and Stern, L. V. (2011), "Fear and closed-end fund discount: investor sentiment revisited", Working paper, Auburn University.

Baker, M., and Wurgler, J. (2007), "Investor sentiment in stock market”, Journal of Economic Perspectives, Vol. 21 No. 2, pp.129-151.

Lee, C.C., Shleifer, A., and Thaler, R. H. (1990), "Anomalies closed-end mutual funds", Journal of Economic Perspectives Vol.4 No. 4, pp. 153-164. 